\title{
Correlation between clinical indices and findings of joint ultrasonography in juvenile idiopathic arthritis with adalimumab therapy
}

\author{
Ryoki Hara*, Tomoyuki Imagawa, Takuma Hara, Masako Kikuchi, Takako Miyamae, Masaaki Mori, Shumpei Yokota \\ From 18th Pediatric Rheumatology European Society (PReS) Congress \\ Bruges, Belgium. 14-18 September 2011
}

\section{Background}

Usefulness of adalimumab (ADA) therapy in patient with rheumatoid arthritis has already established. But the efficacy of ADA in patient with juvenile idiopathic arthritis (JIA) and joint ultrasonography (US) findings of them are still unknown.

\section{Aim}

To evaluate correlation of joint US findings and other clinical indices in JIA patient newly introduced ADA therapy.

\section{Methods}

4 polyarticular JIA ( $\mathrm{p}$-JIA) children diagnosed as JIA according to ILAR criteria were enrolled. All were female. The median age was 12 years (range; 10 to 17 years), and median disease duration was 5.6 years (range; 2.5 to 7.5 years). Two patients were administered prednisolone and methotolexate, One prednisolone only, and one drug free, as preceeding therapy. ADA was administered biweekly at a dose of 40mg per body.

Demographic data were collected. Joint US examination was demonstrated at 0 (prior to administration of ADA), 4, and 24 weeks.

\section{Results}

All of 4 patient had successfully continued ADA therapy for 24 weeks. There were no severe adverse events in this term. At 24 weeks after introduction of ADA, ACR pedi 50 were achieved by 3 patients. The average of MMP-3 at 0 weeks is $441.8(56.1-690.8)$, and fell to

\footnotetext{
* Correspondence: r.hara.ycuped@gmail.com Yokohama City University School of Medicine Department of Pediatrics, Kanagawa, Japan
}

120.4 (45.5 - 185) after 24 weeks. R value of DAS28 and US grade of power doppler (grade 0 to 3 ) is 0.73 .

\section{Conclusion}

Efficacy of ADA therapy in children with JIA is demonstrated, and joint US is a good tool to evaluate disease activity of JIA.

Published: 14 September 2011

doi:10.1186/1546-0096-9-S1-P206

Cite this article as: Hara et al:: Correlation between clinical indices and findings of joint ultrasonography in juvenile idiopathic arthritis with adalimumab therapy. Pediatric Rheumatology 2011 9(Suppl 1):P206.

Submit your next manuscript to BioMed Central and take full advantage of:

- Convenient online submission

- Thorough peer review

- No space constraints or color figure charges

- Immediate publication on acceptance

- Inclusion in PubMed, CAS, Scopus and Google Scholar

- Research which is freely available for redistribution

Submit your manuscript at www.biomedcentral.com/submit
() Biomed Central 